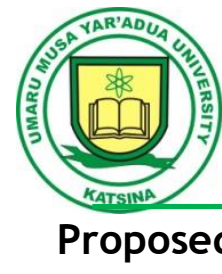

UJMR, Volume 6 Number 1, June, 2021, pp 62 - 69

ISSN: 2616 - 0668

https://doi.org/10.47430/ujmr.2161.008

Received: $04^{\text {th }}$ Mar, 2021

Accepted: $05^{\text {th }}$ April, 2021

\title{
Proposed Hazard Analysis and Critical Control Point (HACCP) Plan for Production of Ready-to-Drink Fura-Da-Nono- A Review
}

\author{
${ }^{* 1}$ Abdullahi, N. (D) ${ }^{2}$ Ndife, J. (D) and ${ }^{3}$ Umar, N. B. (D) \\ 'Department of Food Science and Technology, Kano University of Science and Technology, Wudil, \\ P.M.B 3244, Kano State, Nigeria. \\ 2Department of Food Science and Technology, Michael Okpara University of Agriculture Umudike, \\ PMB 7267, Abia State, Nigeria \\ ${ }^{3}$ Department of Food Science and Technology, Federal Unversity, Dutsin-Ma, PMB 5001, Dutsin-Ma, \\ Katsina State, Nigeria. \\ nurafst@gmail.com; +2348065954460
}

Abstract
The article intended to provide a concise and affluent proposal for the development of HACCP
plan in the production of ready-to-drink Fura-da-Nono using information from reputable literature
and guidelines recommend by food regulatory bodies. Poor personal hygiene, low quality raw
materials and the rudimentary operations involved in the traditional processing of ready-to-drink
Fura-da-Nono accounts for inconsistent quality, shorter shelf-life, poor hygiene and unacceptable
qualities. During processing, materials are exposed to filthy processing environment,
contaminated water, unclean processing equipment and contaminated packaging and storage
containers. Application of HACCP guidelines in the production of ready-to-drink Fura-da-Nono will
significantly improve its safety by assuring acceptance of only good quality raw materials and
ensuring adequate processing along the production chain. These will not only guarantee the
safety of the finished product, but will also ensure better nutritional qualities and acceptable
organoleptic properties.
Keywords: HACCP; Traditional food; Fura; Fura-da-Nono;

\section{INTRODUCTION}

Hazard Analysis and Critical Control Point (HACCP) is a global acceptable program for ensuring food safety. It is used as baseline for development of food safety standards by food regulatory organisation and its implementation by food business operators is mandatory in many nations (Musaj et al., 2012). The HACCP system basically is applied to food processing to identify specific hazards and control measures in order to ensure the safety of foods (Rai et al., 2014). Food safety systems such as HACCP have been applied to prevent contamination of the food (Kim et al., 2020), and its application in traditional foods processing caused significant improvement in their safety(Amoa-Awua et al., 2007). HACCP system has been recognised as an effective and rational means of ensuring food safety from primary production to final consumption, using a "farm to table" methodology (El-Hofi et al., 2010).

There are obvious food safety challenges across West-African sub-region and reported cases of foodborne diseases and outbreaks (Oguntoyinbo, UMYU Journal of Microbiology Research
2014). The unhygienic conditions under which local production occurs include unclean processing environment, use of contaminated water and equipment, contamination from producer and poor storage. These account for poor microbiological quality in many traditional foods and pose grave risks to consumers (Omemu and Adeosun, 2010). Lack of economic resources, purchasing power, more complex food-handling practices, lack of technical expertise and limited personnel have all been cited as possible barriers to HACCP implementation in retail and catering sectors (Karaman et al., 2012). The seven HACCP principles are (1) Conduct a hazard analyses (2) Identify the critical control points (CCPs) (3) Establish critical limits for preventive measures associated with each identified CCP (4) Establish CCP monitoring requirements (5) Establish corrective actions to be taken when monitoring indicates then a deviation from an established critical limit (6) Establish verification procedures and (7) Establish record-keeping and documentation procedures(Abd El-Razik et al., 2016). www.ujmr.umyu.edu.ng 


\section{UJMR, Volume 6 Number 1, June, 2021, pp 1 - $10 \quad$ ISSN: 2616 - 0668}

\section{Safety Aspects of Fura-da-Nono}

Fura is a cereal dumpling produced from pearl millet (Pennisetum glaucum) flour blends with spices, it is a traditional staple food in many West African countries including Nigeria, Ghana, Niger, Cameroun and Burkina-Faso (Jideani et al., 2002; Owusu-Kwarteng et al., 2012). It is a good source of minerals and energy (Durojaiye et al., 2010).Fura is consumed with fermented whole milk (kindirmo) or fermented skimmed milk (Nono) (Jideani et al., 2002), and can be consumed alone or mashed in water to form porridge-like drink (Filli et al., 2012). The production process of Fura is still very crude, involves the use of rudimentary equipment and techniques, this accounts for the inconsistent quality, shorter shelf-life, poor hygiene and unacceptable qualities (Filli et al., 2015). The manual work involved in the local production of Fura, particularly hand-moulding, which is the final operation, can serve as a source of contamination to the finished Fura. Post-process contamination is also very possible by the nature of the handling it received after processing (Anyanwu, 2019). Contamination can also happen during milling which is commonly done in community milling centres (Owusu-Kwarteng et al., 2012).Grinding parts are made using scrap metals whose origin and composition are unknown, this results in heavy metal contamination in foods milled in commercial milling centres (Sinayobye, 2011). The moisture content of Fura is about three times more than that of millet, this makes Fura to be less stable and can provide optimum moisture requirement for the growth of both spoilage and pathogenic microorganisms (Durojaiye et al., 2010).

Nono is traditionally fermented milk which is very similar to yoghurt. Traditional methods of fermenting milk involve the use of indigenous microorganisms, leading to the production of a variety of tastes in fermented milk products (Karenzi et al., 2013). Production of Nono is by back-slopping, a technique that involves the use of the residue from previous fermented batch to inoculate a new batch. The processes also involves the repeated use of fermentation vessels and containers to facilitate the inoculation (Oguntoyinbo, 2014). Dairy products are important food commodities but they are potentially hazardous products when processed under unhygienic conditions. In addition, dairy products are also potential carriers of veterinary drugs, chemical pollutants and microbial toxins (Karaman et al., 2012). Dairy products have been long associated with the transmission of foodborne diseases (Anyanwu, 2019). Interestingly, the application of HACCP program in dairy processing significantly improve the microbial quality and safety of the finished products (Musaj et al., 2012). Critical control points (CCP) in fermented milk processing are raw milk, after pasteurisation, mixing with other ingredients, fermentation, packaging and storage (Musaj et al., 2012; Siddig and Barka, 2015).

Fura is a two in one product supply body with the two important nutrients (protein and carbohydrate) (Anyanwu, 2019). In the production of ready-to-drink Fura-da-Nono, Fura is mashed into Nono and sugar may be added to taste. The mixture of Fura and locally fermented milk (Nono) is called "Fura-da-Nono" and also shortened as Fura by many. Fura-da-Nono is used as a staple food for adults and as a weaning food in some parts of West Africa (Owusu-Kwarteng et al., 2012).

Fura can be considered to be of two different types; the traditional Fura which produced completely by local processing, both the Fura and the Nono were produced traditionally, and modern Fura which can be referred as "Fura da yoghurt" which can be considered to be more hygienic. This brand of Fura is produced by yoghurt companies by mashing traditionally produced Fura in yoghurt with the addition of preservative and low-temperature storage to extend the shelf-life (Anyanwu, 2019). Traditional Fura-da-Nono is normally sold in calabash covered with mat and usually consume using ladle made from a calabash. Fura is mix with Nono in a bowl, usually, one bowl is used in mixing for many customers without washing (Abdulkadir and Mugadi, 2012). Commercial samples of the both types obtained from Abuja (Nigeria) were found to be unsafe for human consumption due to poor microbiological qualities (Anyanwu, 2019).

Pathogenic bacteria found in Fura include Pseudomonas aeruginosa, Serratia mercesens, Bacillus pumillus, Staphylococcus aureus, Salmonella spp and Bacillus alvies (Abdulkadir and Mugadi, 2012). Infectious diseases commonly found in dairy products are Tuberculosis, Brucellosis, Salmonellosis, Staphylococcus mastitis, Listeriosis (Benyagoub and Ayat, 2014), and organisms include Escherichia coli and Staphylococcus aureus (Samet-Bali et al., 2016). 
Proposed HACCP Plan for Production of ReadyTo-Drink Fura-and-Nono

HACCP Plan

Codex (2009) guidelines for establishing a HACCP plan were used in proposing HACCP plan for the ready-to-drink Fura-da-Nono. The plan is designed to identify hazards that can adversely affect the quality and safety of ready-to-drink Fura and apply procedures that will either prevent the occurrence of the hazards or can adequately control them. The plan identifies different steps along the production chains of both Fura and Nono before and after combining them. The plan is basically developed based on the following questions.

1. Is there any hazard associated with ready-to-drink Fura?

2. What are the precise points along the production line that are suspected to be the source(s) of hazard?

3. At what point can control be precisely applied to curtail the hazard?

4. What are the monitoring procedures for ensuring the effectiveness of the control?

\section{Hazard Analysis of the Proposed Control Measures \\ Each of the two major ingredients (millet and milk) used in the production of Fura-da-Nono and processing operations were studied. Possible hazards and control measures in the raw materials and processing operations were identified and listed in Table 1. \\ Identification of Critical Control Points during Processing}

Critical control points are points along the processing chain where control can be applied to prevent, eliminate or reduce hazard to acceptable levels. Critical control points were identified using Codex (2009) decision tree. Critical limits for microbiological criteria of raw materials, intermediate and fished products were chosen based on the recommendations of International Commission on Microbiological Specifications for Foods (ICMSF, 2011). ICMSF guidelines are used in evaluating process control and product acceptance during food processing. Critical limits for chemical contaminants were chosen based on general standard for contaminants and toxins in food and feed (CODEX STAN 193-1995) published by Codex Alimentarius Commission (Codex, 2014).

A total of 10 CCPs were identified (Figure 1), six CCPs were identified in the production of Fura, two in the production of Nono, and two in the combined Fura-da-Nono.

\section{Critical Limit and Corrective Actions}

Critical limit is a criterion that separate acceptability from unacceptability, it is used as a safety boundary to control identified hazard. Critical limits for each of the identified CCP were established (Table 2). This includes critical limits for biological, chemical and physical hazards. Also, corrective actions for each of the identified CCP was established (Table 2), this includes rejection of poor quality raw materials, ingredients and packaging materials, modification of processing conditions and good manufacturing practices.

\section{Verification and Record-Keeping}

Verification for raw materials and ingredients will include supplier's guarantee, visual inspection and laboratory tests. While visual inspection, laboratory test and adjustment of processing conditions will be used for verification of intermediate and finished products. Records to be kept will include supplier's guarantee, reports for visual observations, results of laboratory analyses (microbial, chemical and physical) and processing conditions such as time, temperature, $\mathrm{pH}$, etc. 


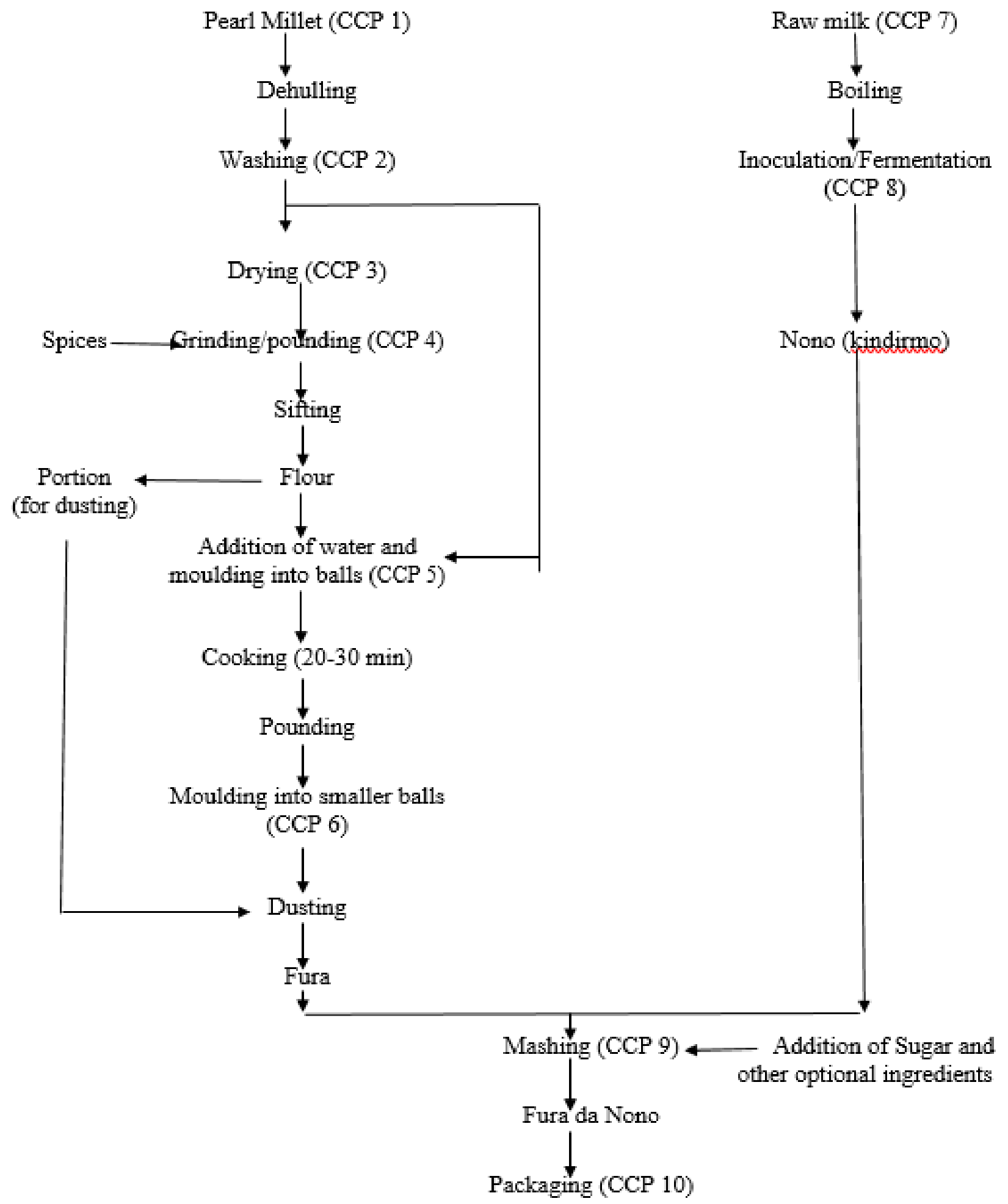

Figure 1: Critical Control Points in the Production of Ready-to-Drink Fura-da-Nono 
Table 1: Suspected Hazards and their Control Measures

\begin{tabular}{|c|c|c|c|c|}
\hline \multirow{2}{*}{$\begin{array}{l}\text { Processing step } \\
\text { Millet }\end{array}$} & \multicolumn{3}{|c|}{ Hazard } & \multirow[t]{2}{*}{ Control Measure } \\
\hline & Biological & chemical & Physical & \\
\hline Raw millet (CCP 1) & Microorganisms & $\begin{array}{l}\text { Mycotoxins, pesticides } \\
\text { residue, heavy metals }\end{array}$ & $\begin{array}{l}\text { Impurities and foreign } \\
\text { matter }\end{array}$ & $\begin{array}{l}\text { Awareness and use of } \\
\text { good quality raw } \\
\text { materials from certified } \\
\text { suppliers }\end{array}$ \\
\hline Dehulling & Non & Non & Non & \\
\hline Washing (CCP 2) & $\begin{array}{l}\text { Spoilage and pathogenic } \\
\text { microorganisms }\end{array}$ & & & Use of potable water \\
\hline Draying (CCP 3) & $\begin{array}{l}\text { Spore forming bacteria, } \\
\text { mould and yeast }\end{array}$ & & Impurities and dust & Mechanical drying \\
\hline $\begin{array}{l}\text { Grinding/pounding and } \\
\text { addition of spices } \\
\text { (CCP } 4)\end{array}$ & Cross-contamination & & $\begin{array}{l}\text { Impurities and foreign } \\
\text { matter }\end{array}$ & $\begin{array}{c}\text { Good manufacturing } \\
\text { practice and use of good } \\
\text { quality spices }\end{array}$ \\
\hline Sifting & & & & \\
\hline $\begin{array}{l}\text { Addition of } \\
\text { water/moulding (CCP 5) }\end{array}$ & $\begin{array}{l}\text { Spoilage and pathogenic } \\
\text { microorganisms } \\
\text { (including Human) }\end{array}$ & & & $\begin{array}{c}\text { Use of potable water, use } \\
\text { of hand gloves }\end{array}$ \\
\hline Cooking & Nil & Nil & Nil & \\
\hline Pounding & Non & Non & Non & \\
\hline Moulding (CCP 6) & $\begin{array}{l}\text { Spoilage and pathogenic } \\
\text { microorganisms } \\
\text { (including Human) }\end{array}$ & & & $\begin{array}{l}\text { Use of hand gloves and } \\
\text { use of anti-microbes } \\
\text { during dusting }\end{array}$ \\
\hline Nono & & & & \\
\hline Raw milk (CCP 7) & $\begin{array}{c}\text { Pathogenic and spoilage } \\
\text { organisms }\end{array}$ & & & $\begin{array}{l}\text { Good quality } \\
\text { (pasteurised) milk from } \\
\text { certified suppliers }\end{array}$ \\
\hline $\begin{array}{l}\text { Boiling } \\
\text { Inoculation (back slope)/ } \\
\text { Fermentation (CCP 8) } \\
\text { Fura-da-Nono }\end{array}$ & $\begin{array}{l}\text { Spoilage and pathogenic } \\
\text { microorganisms }\end{array}$ & & & Use of starter culture \\
\hline $\begin{array}{l}\text { Addition of ingredients } \\
\text { (CCP 9) }\end{array}$ & $\begin{array}{l}\text { Spoilage/Pathogenic } \\
\text { microorganisms }\end{array}$ & & & $\begin{array}{l}\text { Use of good quality } \\
\text { ingredients }\end{array}$ \\
\hline Packaging (CCP 10) & $\begin{array}{l}\text { Cross-contamination } \\
\text { and human pathogens }\end{array}$ & & & Maintaining GMP \\
\hline
\end{tabular}


Table 2: Critical Limits and Corrective Action of the CCPs

\begin{tabular}{|c|c|c|c|c|}
\hline \multirow{2}{*}{$\begin{array}{l}\text { Processing step } \\
\text { Millet }\end{array}$} & \multicolumn{3}{|c|}{ Proposed Critical Limit } & \multirow[t]{2}{*}{ Proposed corrective action } \\
\hline & Microbiological & Chemical & Physical & \\
\hline Raw millet (CCP 1) & ${ }^{1} \mathrm{APC}<10^{5} \mathrm{cfu} / \mathrm{g}$ & $\begin{array}{l}{ }^{2} \mathrm{Aflatoxin} \text { (total) } \leq 15 \\
\mu \mathrm{g} / \mathrm{kg} \\
\text { Pesticide residue and } \\
\text { heavy metals }<5 \mathrm{ppm}\end{array}$ & $\begin{array}{l}<2 \% \text { of physical } \\
\text { contaminant }\end{array}$ & $\begin{array}{l}\text { Reject raw material with higher } \\
\text { microbial counts and higher chemical(s). } \\
\text { Re-clean grains with impurities }\end{array}$ \\
\hline \multicolumn{5}{|l|}{ Dehulling } \\
\hline Washing (CCP 2) & $\begin{array}{l}\text { Coliform andE. coli }=\text { Not } \\
\text { to be detected in } 25 \mathrm{~g} \\
{ }^{1} \mathrm{APC}<10^{3} \mathrm{cfu} / \mathrm{ml}\end{array}$ & & & $\begin{array}{l}\text { Reject processing water with faecal } \\
\text { contamination and/or higher APC }\end{array}$ \\
\hline Draying (CCP 3) & & & $\begin{array}{l}\text { At } 70{ }^{\circ} \mathrm{C} \text { for } 6 \text { hrs with } \\
\text { even air circulation }\end{array}$ & Adjust processing condition to optimum \\
\hline $\begin{array}{l}\text { Grinding/pounding and } \\
\text { addition of spices } \\
\text { (CCP 4) }\end{array}$ & $\begin{array}{l}\text { Coliformand } E \text {. coli }=\text { Not } \\
\text { to be detected in } 25 \mathrm{~g} \\
{ }^{1} \mathrm{APC}<10^{5} \mathrm{cfu} / \mathrm{ml}\end{array}$ & & & $\begin{array}{l}\text { Reject intermediate product and sanitise } \\
\text { the processing equipment }\end{array}$ \\
\hline \multicolumn{5}{|l|}{ Sifting } \\
\hline $\begin{array}{l}\text { Addition of water/moulding } \\
\text { (CCP 5) }\end{array}$ & $\begin{array}{l}\text { Coliformand } E \text {. coli }=\text { Not } \\
\text { to be detected in } 25 \mathrm{~g} \\
{ }^{1} \mathrm{APC}<10^{5} \mathrm{cfu} / \mathrm{ml}\end{array}$ & & & $\begin{array}{l}\text { Reject processing water with faecal } \\
\text { contamination and/or higher APC }\end{array}$ \\
\hline \multicolumn{5}{|l|}{ Cooking } \\
\hline Moulding (CCP 6) & $\begin{array}{l}\text { Coliformand } E \text {. coli }=\text { Not } \\
\text { to be detected in } 25 \mathrm{~g} \\
{ }^{1} \mathrm{APC}<10^{3} \mathrm{cfu} / \mathrm{ml}\end{array}$ & & & $\begin{array}{l}\text { Reject intermediate product in case of } \\
\text { faecal contamination. } \\
\text { Re-cook product with high APC }\end{array}$ \\
\hline \multicolumn{5}{|r|}{ 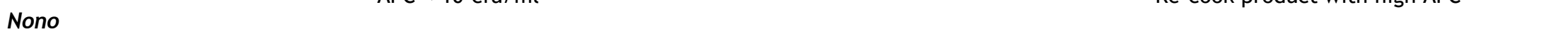 } \\
\hline Raw milk (CCP 7) & $\begin{array}{l}\text { ColiformandE. coli }=0 \\
{ }^{1} \mathrm{APC}<10^{5} \mathrm{cfu} / \mathrm{ml}\end{array}$ & $<5 \mathrm{ppb}$ & & Reject any doubtful raw materials \\
\hline \multicolumn{5}{|l|}{ Boiling } \\
\hline $\begin{array}{l}\text { Inoculation (back slope)/ } \\
\text { Fermentation (CCP 8) }\end{array}$ & & & At $30-35{ }^{\circ} \mathrm{C}$ & $\begin{array}{l}\text { Adjust processing condition and inoculate } \\
\text { with starter culture }\end{array}$ \\
\hline \multicolumn{5}{|l|}{ Fura-da-Nono } \\
\hline $\begin{array}{l}\text { Addition of ingredients (CCP } \\
\text { 9) }\end{array}$ & $\begin{array}{l}{ }^{1} \text { ColiformandE. coli }=\text { Not } \\
\text { to be detected in } 25 \mathrm{~g} \\
{ }^{1} \mathrm{APC}<10^{3} \mathrm{cfu} / \mathrm{ml}\end{array}$ & & & Reject any doubtful ingredient \\
\hline Packaging (CCP 10) & $\begin{array}{c}\text { Coliformand } E \text {. coli }=\text { Not } \\
\text { to be detected in } 25 \mathrm{~g} \\
{ }^{1} \mathrm{APC}<10^{3} \mathrm{cfu} / \mathrm{ml}\end{array}$ & & & $\begin{array}{l}\text { Reject any doubtful package and observe } \\
\text { good manufacturing practices }\end{array}$ \\
\hline
\end{tabular}

1- ICMSF (2011)

2- Codex(2014)

APC; Aerobic Plate Count 


\section{CONCLUSION}

Unhygienic processing and handling, as well as post-processing contamination potentially, constitute microbial hazards of Fura-da-Nono. HACCP as a global acceptable program for ensuring food safety can guarantee the safety of Fura when properly applied through the identification of potential hazards along the production chain and application of appropriate corrective actions where ever there is deviation. Lack of formal education, poor economic resources, poor purchasing power, lack of awareness on the danger associated with poor food hygiene and lack of technical expertise are the possible barriers to HACCP application in the traditional production of Fura. An effective HACCP program will improve the safety of Fura and extend its shelf-life.

\section{REFERENCES}

Abd El-Razik, M. M., Hassan, M. F. Y., and Gadallah, M. G. E. (2016). Implementation of HACCP Plan for the Production of Egyptian Kishk (A Traditional Fermented Cereal-Milk Mixture). Food and Nutrition Sciences, 07, 1262-1275. https://doi.org/10.4236/fns.2016.713116

Abdulkadir, M., and Mugadi, A. G. (2012). Bacteriological Examination of Fura Da Nono (Fermented Milk; Cereals Mix) Sold in Some Selected Areas of Birnin Kebbi Metropolis. ARPN Journal of Science and Technology, 2, 333-340.

Amoa-Awua, W. K., Ngunjiri, P., Anlobe, J., Kpodo, K., Halm, M., Hayford, A. E., and Jakobsen, M. (2007). The effect of applying GMP and HACCP to traditional food processing at a semi-commercial kenkey production plant in Ghana. Food Control, 18(11), 1449-1457. https://doi.org/10.1016/j.foodcont.2006 .10 .009

Anyanwu, N. C. J. (2019). Microbiological and comparative analysis of indigenous and semi- industrial fermented milk drinks ( Fura da Nono and Fura da Yoghurt ) sold in Nigeria' $s$ capital. International Journal of Bioassays, 8. https://doi.org/10.14303/ijbio.2019.8.1. 5

Benyagoub, E., and Ayat, M. (2014). Hazard analysis and testing for implemented a HACCP system at a dairy factory in South

\section{RECOMMENDATIONS}

1. Fura should always be produced from high quality raw materials with no physical, chemical or biological hazard.

2. Good manufacturing practices should be observed throughout the production processes of Fura.

3. Environmental and personal hygiene should always be observed by producers and retailers.

4. Utensils and equipment used in the production should be clean.

5. Awareness on the danger of poor food quality should be created among Fura producers and retailers.

6. Appropriate packaging system should be designed to prevent post-process contamination

West Algeria. Food Science and Quality Management, 32, 57-67.

Codex Alimentarius Commission (2014). General Standard for Contaminants and Toxins in Food and Feed. (CODEX STAN 193-1995).

Durojaiye, A. F. A., Falade, K. O., and Akingbala, J. O. (2010). Chemical composition and storage properties of fura from pearl millet (pennisetum americanum). Journal of Food Processing and Preservation, 34(5), 820-830. https: / / doi.org/10.1111/j.17454549.2009.00397.x

El-Hofi, M., El-Tanboly, E. S., and Ismail, A. (2010). Implementation of the hazard analysis critical control point (haccp) system to uf white cheese production line. Acta Scientiarum Polonorum, Technologia Alimentaria, 9(3), 331-342.

Filli, K. B., Nkama, I., Jideani, V. A., and Abubakar, U. M. (2015). Effect of Process Variables on Some System Parameters and Physical Properties of Millet-Soybean Fura Extrudates. Journal of Food Studies, 4(1), 1-33. https: / / doi.org/10.5296/jfs.v4i1.1727

Filli, K. B., Nkama, I., Jideani, V. A., and Ibok, I. U. (2012). System Parameters and Product Properties Responses During Extrusion of Fura from Millet-Soybean Mixtures. Nigerian Food Journal, 30(1), 82-100. https://doi.org/10.1016/s01897241(15)30017-5

Food Hygiene: Basic Texts, $4^{\text {th }}$ Edition. Codex Alimentarius Commission (Rome, 2009), 
Joint Food StandardsProgramme established by the Food and Agriculture Organization of theUnited Nations (FAO) and the World Health Organization (WHO). Pp 6-22.

International Commission on Microbiological Specifications for Foods (ICMSF) (2011) Microorganisms in Foods 8: Use of Data for Assessing Process Control and Product Acceptance. Springer, New York.

Jideani, V. A., Nkama, I., Agbo, E. B., and Jideani, I. A. (2002). Mathematical modeling of odor deterioration of millet (Pennisetum glaucum) dough (fura) as affected by time-temperature and product packaging parameters. Cereal Chemistry, 79(5), 710-714. https: / /doi.org/10.1094/CCHEM.2002.79. 5.710

Karaman, A. D., Cobanoglu, F., Tunalioglu, R., and Ova, G. (2012). Barriers and benefits of the implementation of food safety management systems among the Turkish dairy industry: A case study. Food Control, 25(2), 732-739. https://doi.org/10.1016/j.foodcont.2011 .11 .041

Karenzi, E., Thonart, P., Mashaku, A., Munyanganizi, B., and Nshimiyimana, A. M. (2013). Kivuguto traditional fermented milk and the dairy industry in Rwanda. A review. Biotechnology, Agronomy and Society and Environment, 17(2), 383-391.

Kim, D. H., Cho, W. Il, and Lee, S. J. (2020). Fault tree analysis as a quantitative hazard analysis with a novel method for estimating the fault probability of microbial contamination: A model food case study. Food Control, 2020. https://doi.org/10.1016/j.foodcont.2019 .107019

Musaj, A., Bijo, B., Hoxha, A., and Gjinovci, V. (2012). The Study of HACCP In Dairy -
Yogurt Product. Macedonian Journal of Animal Science, 2(3), 313-320. https: / /doi.org/10.1016/j.radphyschem. 2014.05.033

Oguntoyinbo, F. A. (2014). Safety Challenges Associated with Traditional Foods of West Africa. Food Reviews International, 30(4) 338-358. https: / / doi.org/10.1080/87559129.2014. 940086

Omemu, A. M., and Adeosun, O. F. (2010). Evaluation of hazards and critical control points of ogi in small scale processing centres in Abeokuta, Nigeria. Journal of Applied Biosciences, 29, 1766-1773.

Owusu-Kwarteng, J., Akabanda, F., Nielsen, D. S., Tano-Debrah, K., Glover, R. L. K., and Jespersen, L. (2012). Identification of lactic acid bacteria isolated during traditional fura processing in Ghana. Food Microbiology, 32(1), 72-78. https://doi.org/10.1016/j.fm.2012.04.01 0

Rai, R., Kharel, N., and Tamang, J. P. (2014). HACCP model of kinema, a fermented soybean food. Journal of Scientific and Industrial Research, 73, 588-592.

Samet-Bali, O., Felfoul, I., Lajnaf, R., Attia, H., and Ayadi, M. A. (2016). Hygienic quality of "Rayeb", a traditional Tunisian fermented cow's milk. International Food Research Journal, 23(1), 366-369.

Siddig, E. A. M., and Barka, M. K. B. (2015). Evaluation and Implementation of Hazard Analysis and Critical Control Points System (HACCP) in Stirred Yoghurt Plant. Sudan University of Science and Technology.

Sinayobye, E. (2011). Size Reductionof Food Commodities and Food Safety in. African Journal of Food, Agriculture, Nutrition and Development, 11(6), 5282-5300. 